\title{
Contemporary International Relations and the BRICS Geopolitics of State Capitalism
}

\author{
Professor Johannes Tsheola \\ Department of Development Planning \& Management, University of Limpopo \\ johannes.tsheola@ul.ac.za
}

\author{
Doi:10.5901/mjss.2014.v5n25p238
}

\begin{abstract}
This article posits that the BRICS set serves to create a "regional" business space for exclusive operations of state-owned enterprises (SOEs) of member states. Far from being forecast as leading emerging economies of future significant standing on the global stage, the BRICS of Brazil, Russia, India, China and South Africa is trapped in the binary-paralysis of private-public partnership governance. The article examines the BRICS set conditionalities and principles for conduct of international relations in order to demonstrate that member countries' continued reverence of state capitalism governance, manifested through SOEs "champions", will precipitate intra-set economic and political conflict in ways that perpetuate domestic political-economy of poverty and inequality. It argues that state capitalism, and a nuance hybrid of SOEs that are supported through public funds in order to operate on the global business platform in the same way as private multinational corporations that pursue commercial financial interests, does not serve societal goals of justice and equity. Given that the establishment of the BRICS is framed on the set being the centre of future global growth, consolidation of state capitalism and the nuance hybrid of SOEs imply that domestic poverty and inequality will continue unabated, as public investment share of education and health remains negligible. The article demonstrates that state capitalism and SOEs "champions" governance, is inherently biased towards greater public investment in industrial production rather than social objectives. It concludes that multidimensional and income poverty will continue to be intensive whilst inequality remains stark among the BRICS member states, whilst their cultural, historical and ideological diversities stimulate economic and political conflict in international relations.
\end{abstract}

Keywords: International Relations; BRICS; Private-Public Binary; State Capitalism; State-owned Enterprises

\section{Introduction}

Throughout the colonial period, notwithstanding governmentality and extraversion, economics flourished "on terms of trade determined more by political and military power than by competitive efficiency" (Huggett \& Robinson, 1996, p.159). The present capitalist world-economy is defined at its core by elements such as "capital, money, commodities, markets and states" (Wallerstein, 1979 cited in Langton, 1996, p.208), which are drive through cultural, historical and ideological praxis. Hence, contemporary international relations studies transcend the conventional focus on inter-state cooperation, conflict, negotiations and diplomacy, in order to account for cultural, historical and ideological aspects that underline national pride, glory, morality and religious zeal predominant in global governance (Chandler, 2006; Parker, 2010; Zielonka, 2012). It is evident that wars fought across the world today are fundamentally about conduct of some global actors seeking to "civilize" others. For instance, Ukraine is increasingly being split into the European-oriented and Russian-inclined factions that are engaged in a fierce war, which claimed innocent civilian lives from the Netherlands, Australia, Britain and South Africa, among other countries. Also, the Islamic State of Iraq and Syria (ISIS), the so-called Russian-separatists and Hamas, just for illustration, are non-state global actors that have shaped contemporary international relations. Contemporary global order and agendas are therefore facilitated and shaped by a complexity of state and non-state actors, whose conduct of international relations cannot be adequately understood through the conventional conceptions of global state, great powers and hegemons (Zielonka, 2012). Indeed, it would be inaccurate to describe the European Union (EU), Taliban, ISIL, Russian-separatists and Hamas, among others, as global states, great powers or hegemons. In this same context, pertinent questions of the role of the BRICS set's geopolitics of state capitalism in contemporary international relations need to be framed.

Does the BRICS (Brazil, Russia, India, China and South Africa), a set which is home to almost $40 \%$ of the world population, have the capabilities to (re)shape the global order and/or facilitate the international agenda? Presently, accusations are flying around regarding Russia's role in the bombing of the Malaysian Airlines MH17 on 17 July 2014 over Ukraine territory; and, the BRICS has nowhere revealed its face as a set in this regard. The same is true for the wars in Libya, Egypt, Syria and, now, Israel and Palestine. Is the BRICS geopolitics as a set consequential on the global 
stage? Perhaps, the BRICS set is only identifiable through its member states' reverence for state capitalism amidst domestic poverty and inequality. Global actors become passive where inaction is the most appropriate form of facilitating global agendas and shaping international order/disorder, because their readiness to interfere in world affairs to serve nationalistic interests and objects is palpable. To this extent, the imperial paradigm is preferred for the theorization of the BRICS geopolitics of state capitalism in order to understand its inconsequential positioning in contemporary international relations. This article takes interest in the BRICS set conditionalities and principles, which define its fragmentary geopolitical self-imaginary and, therefore, inconsequential standing in world affairs. With the BRICS set's reverence of state capitalism, openness and non-interference, it can be expected that member states will be in perpetual economic conflict, therefore naturally seeking to exploit their power capabilities to manipulate markets to their self-interests of exporting poverty and importing wealth.

\section{Contemporary International Relations and the BRICS Emerging Economies}

Contemporary international relations involve extraterritorial interferences, which are driven through nationalist and religious sentiments of pride, glory and morality. The latter constitute the basis for civilizing missions which, sometimes, consist of irrationality that derive from "complex historical, cultural and ideological processes" (Zielonka, 2012, p.519). The imperial vision, purpose and policies as well as the role of the global actor in their motivation, integration and legitimization is prescribed in fuzzy legal or illegal and formal or informal, as well as steeply mutable and uncertain, civilizing missions; and, their pursuit scarcely rely on coercion, oppression or exploitation (Hardt \& Negri, 2000; Pitts, 2005; Pomeranz, 2005; Kearns, 2009; Parker, 2010; Zielonka, 2012). In the final analysis, extraterritorial actions of interference are guided to serve domestic interests and objectives.

Within international relations, global actors appear to be involved in a perpetual state of political and economic conflict because these global interactions are deeply complex and steeply paradoxical; and, the global settings are in a state of continuous and fast evolution (Zielonka, 2012). According to Huggett \& Robinson (1996, p.159),

"... human societies evolved social and economic systems of relative complexity that allowed them both to consolidate within 'natural' boundaries and simultaneously to enlarge political control over non-contiguous territory. In the process of enlargement cultures inevitably came into conflict and out of this conflict they began slowly to homogenize. .... Larger and more powerful ones steadily extended their spheres of influence and control".

To this extent, the BRICS set's differentness of member states can be expected to agitate for conflict rather than unison action, especially due to the grouping's globalist modernity founding principles. As Langton (1996, p.208) puts it, "Global cities and backward provinces, cores and peripheries, First World and Third World are not inherent in nature, but (are) produced by the organization of space by flows of capital and commodities". That is, capital, which is the hallmark of the capitalist economic system, "produces a space through which places are linked, and in which they are organized", in the process of producing commodities (Smith, 1984 cited in Langton, 1996, p.208). The global agents driving the capitalist system are driven by distinct nationalist cultures, histories and ideologies (Pitts, 2005; Parker, 2010; Zielonka, 2012).

That is, the multiple state and non-state actors that are continuously (re)shaping and facilitating the regional and global agendas as well as international order/disorder are virtual empires whose interferences are erroneously construed as civilizing, peaceful, developmental and world-order inducing (Hardt \& Negri, 2000; Pitts, 2005; Pomeranz, 2005; Chua, 2007; Kearns, 2009; MacDonald, 2009; Zielonka, 2012). But it is imperative to note that "an imperial system represents an inherently unstable political condition" (Goodall, 1987, p.221). Whereas oppression and exploitation are tacitly inseparable from the contemporary imperial actors' conduct of international relations, their value-laded core mission is assumed and presented as peaceable, even when extraterritorial actions involve evident atrocities (Pomeranz, 2005; Kearns, 2009; MacDonald, 2009; Parker, 2010), especially in cases where the agents are cast as illegal, and informal polities.

The source of power for all global actors transcends the conventional capabilities described in the notions of democracy, nation, state, economics, politics, demographics, military and hegemon, to geopolitical self-imaginary of the polities, which in return (re)shape the conduct of international relations. As Huggett \& Robinson (1996, p.161) put it,

\footnotetext{
"The economically strong and powerful exploited resources on a global scale, rather than on the scale of a single region or country (and) .... By the end of the nineteenth century, and through the early years of the twentieth, the industrial nations of the earth were poised to shift global competition into the arena of global war".
} 
Just like Russia, the European Union and the USA would not accept responsibility for having catalysed the seed that bred the ongoing violence in Ukraine, notwithstanding the fact that they had each fully encouraged and supported the public contestations that are at the root of the presently deeply divided society. Whilst agitating for civil disobedience, imperial actors would have disguised their actions and/or inactions as service to the cause of freedom, democracy, good governance, human rights, global order, stability and security as well as defence against barbarism and terrorism. Governments have, however, continued to hold more power capabilities because their "role in projecting and exercising political power at every level from the local to the international" has been escalated with industrial developments and transformation of social economies of the $18^{\text {th }}$ and $19^{\text {th }}$ centuries (Huggett \& Robinson, 1996, p.160). Thus, Russia is accused of bolstering the power capabilities of the Ukrainian separatists.

As a result, the nuance imperial paradigm attempts to account for the role of cultures, histories and ideologies in shaping the global order/disorder and facilitating global agendas in the complex international relations (Pitts, 2005; Pomeranz, 2005; Zielonka, 2012). Civilizing missions of the global actors are inevitably contradictory and paradoxical because their underling geopolitical self-imaginary is a function of the complexity inherent in the diversity of cultures, histories and ideologies (Pitts, 2005; Pomeranz, 2005; Kearns, 2009; Zielonka, 2012). According to Huggett \& Robinson (1996, p.160),

\footnotetext{
"With the evolution of urban industrial cultures, and powered by differentials in industrial output, the political and economic transformation of all societies began to accelerate. Variations in the rate of change, however, exacerbated the differences between them. Countries began to separate more emphatically into those that 'had' and those that 'had not"'.
}

Hence, the BRICS set cannot be readily accepted as a global actor of reckoning merely because of its population and economic size. For non-state actors such as the BRICS set, the geopolitical self-imaginary in the international management geopolitics is subservient to specific cultures, histories and ideologies, which are in this case starkly unique and different. The BRICS set is a disparate grouping in all the ways, except for the imposture of varieties of state capitalism governance and hybrids of SOEs. Importantly, even this form of governance and SOEs are not culturally, historically and ideologically monolithic across the BRICS set.

\section{Binary-Paralysis and the Private-Public Partnership Hybrids}

Varieties of capitalism practiced by most emerging economies are, conceptually, reflexive hybrids of the state-market nexus (Kolo, 2008; Bradley \& Donway, 2010; Dean, Browne \& Oster, 2010; Karon, 2011; Coy, 2012; Goryunov, 2012; Lubman, 2012; Webb, 2012; Yi-Chong, 2012). The resurgence of SOEs on the global business stage has again "raised philosophical and ideological debates on the role of the state, the state versus markets, and varieties of capitalism" (YiChong, 2012, p.2). Capitalism has since at least the $18^{\text {th }}$ century steadily replaced the feudal system, wherein development action was construed as only operations of individuals in free markets, to the exclusion of government action (Marais, 2001; Legum, 2002). After the 1960s, the development discourse and practice exulted neoclassical orthodoxy, rejecting the Keynesian alternative of economics as a value-laded servant of humanity's development, redistributive justice and political redress. Indeed, the latter half of the twentieth century was predominated by national development policies that are predicated on scantly understood buzzwords such as privatization, commercialization, efficiency, economic and monetary reforms, structural adjustments, trade liberalization, democratization and commodification, among others (Simon, van Spengen, Dixon \& Narman, 1995; Veseth, 1998; Marais, 2001; Legum, 2002). Effectively, the globalist neoliberal modernity came to triumph over the statist conceptions of economics and development. The free market was thought to be superior to the state (Koppel, 1990).

Whereas the globalist neoliberal modernity discourse overshadowed narratives about people emancipation, selfenhancement and self-discovery (Mkandawire, 2011), contestations about whether the state or free market governance of economics is ideal persisted, causing in return a conceptual binary-paralysis. Whereas the globalist neoliberal modernity perspective came to captivate the development discourse, especially after the mid-20 $0^{\text {th }}$ century, the binaryparalysis of the free markets and the Keynesian interventionist state persisted. The triumphalism of market economics amidst endemic poverty and inequality as well as the recent global financial crises were met with the ascendency of state capitalism governance, which relied solely on State-owned Enterprises (SOEs). State capitalism governance was meant to incorporate the critique of free markets by invoking public institutions' visible hand to supplement the invisible hand. Hence, there has been a buzz about private-public partnership in SOEs under state capitalism; and, all the BRICS member states are captivated by variants of this form of governance. To appreciate the effects of state capitalism 
governance on domestic structures of poverty and inequality as well as its capacity to fundamentally alter domestic relations of production and consumption through the determination of control and ownership of SOEs, it is necessary to examine free market capitalism more closely as "the logic of a system" as conceptualized by Langton (1996).

The activities that underwrite capitalism require, as per this nomenclature, capital. The latter can be "in the form of machines, buildings and other infrastructures, on and in which work is done, and variable capital comprising stocks or raw materials, finished goods, and the money used to pay for work in advance of selling products" (Langton, 1996, p.206). In the abstract, a person's operations become capitalist in as far as they appropriate increasing wealth (Langton, 1996; Legum, 2002; Nabudere, 2006; Mbeki, 2009). To multiply itself, money has to therefore endlessly chase after "machinery and other fixed capital through which energy, labour and materials are combined to make commodities", whilst perpetually changing them in return (Langton, 1996, p.207). In such a capitalist economic system, land, labour and money become fictional commodities because of the erroneous assumption that "anything that is bought and sold must have been produced for sale" (Polanyi, 1957, pp.42, 72 cited in Langton, 1996, p.207). Through a process of commodification, "Money is borrowed at interest in order to invest, land is purchased to yield rent, and the labour of workers is bought for wages" (Langton, 1996, p.207). That is, the process of commodification of capital "requires "the Rise of the Market, the Rise of the Exchange Economy ..., which is antecedent to [the] Rise of Capitalism"' (Hicks, 1969, p.7 cited in Langton, 1996, p.207). To this extent, the capitalist system lacks a human face because it evolves around the fictional commodification of money in order to engender "anonymity" of economic exchange and extrication from "social interactions" (Hart, 1986 cited in Langton, 1996, p.207). The BRICS member states have ignored these apparent contradictions in economics as "the logic of a system" and adopted the bourgeois ideologies of state capitalism, thereby establishing cohorts of "bureaugarchs" where politics and business became blurred (Hall \& Soskice, 2001; Gabriel, 2003; Mbeki, 2009; Desai, Maharaj \& Bond, 2011; Hsing, 2011; Biko, 2013; Habib, 2013; Parsons, 2013; Qwabe, 2013).

To benefit from the capitalist system, individuals are required to own and control commodified resources in order that they may produce in line with market signals and dictates (Langton, 1996; Hall \& Soskice, 2001; Marais, 2001; Legum, 2002; Mbeki, 2009; Alloggio \& Thomas, 2013; Biko, 2013). Hence, the fundamental capitalist belief has been that privatization and free markets are more efficient and equitable than public ownership and control. Free markets are assumed to create the possibility for "maximum mutual economic benefit" through "maximum freedom" of entry into the exchange relationships (Wallace, 1990, p.18 cited in Langton, 1996, p.207). In reality though, as Langton (1996, p.207) puts it, "These necessary freedoms are contradictory" because "Owners of capital benefit from impoverishing their workers and suppliers, but only in so far as they are not their customers". To this extent, "free markets are not ... benign arrangements operating to everyone's benefit, but (they) create contradictions between individuals' interests as buyers and sellers, and between the rates of profit and capital accumulation and the rate of consumption" (Langton, 1996, p.208). Hence, state capitalism governance is founded on the hope that the visible hand of public institutions would supplement the invisible hand of free markets (Glemarec \& Puppim de Oliviera, 2012) in order to reflexively incorporate the critique about contradictions (Koppel, 1990; Veseth, 1998; Hall \& Soskice, 2001; Legum, 2002; Nabudere, 2006; Mbeki, 2009; Orrell, 2010; Alloggio \& Thomas, 2013). Thus, Wallerstein's (1979, p.159 cited in Langton, 1996, p.208) conception of the defining characteristics of the capitalist world-economy is that it combines "freedom and unfreedom" because it seeks to resolve the inherent contradictions by "imposing controls on the freedoms of buyers or sellers, even in 'free' markets". It is in this context that this article finds the establishment of the BRICS set of member states that are characterized as emerging economies based on varieties of state capitalism, amidst deep domestic poverty and inequality, to be awkward. Langton's $(1996$, p.208) formulation succinctly describes the protracted geopolitics of capitalism at the national scale and in international relations thus:

"... states equalize minimum levels of well-being, supervise uniform rules for economic and other interpersonal relationships within their boundaries, and articulate their members' interests externally by manipulating international markets so that foreign goods are cheap and goods sold abroad are dear. All states aim to export poverty and import wealth simultaneously. Like individuals, they are inevitably in economic conflict, and succeed to the extent that they have the power to manipulate markets to their advantage".

With the BRICS set's reverence of state capitalism, openness and non-interference, it can be expected that the member states will be in perpetual economic conflict, therefore naturally seeking to exploit their power capabilities to manipulate markets to their self-interests of exporting poverty and importing wealth. For these same reasons, the state capitalism governance is not suited for the BRICS set where poverty and inequality are endemic. 


\section{BRICS Conditionalities, Principles and State Capitalism Governance}

The original 2001 framing of the BRICs was conceived by the Goldman Sachs, which forecast that the emerging economies of Brazil, Russia, India and China would become engines of future global growth on account of their population sizes and potential to increase elasticity of demand for global products for industrialized economies (Wilson \& Purushothaman, 2003; O'Neill, Wilson, Purushothaman \& Stupnytska, 2005; Wilson, Kelston \& Ahmed, 2010). However, this forecast was based on the assumption that these countries would successfully establish macro-stability, especially price stability; develop good institutions, including legal systems, functioning markets, educational systems, financial institutions and so on; intensify their openness to trade and foreign direct investment (FDI); and, improve domestic literacy and education (Wilson \& Purushothaman, 2003; O'Neill et al., 2005; Wilson et al., 2010). These conditionalities describe the preconditions required for the globalist neoliberal modernity, growth-oriented policies (Glosny, 2010; Bell, 2011). But these policies are overwhelmingly blamed for perpetuating poverty and inequality within developing countries. On the global stage, the BRICs set, even with South Africa as BRICS, as Cooper (2009, n.p.) puts it, remained "a sideshow to the main 'club' competitions" including among others the EU, G-8 and G-20. The BRICS set is identifiable by the stark differences and discrepancies of the member states, politically and economically (MacFarlane, 2006; Tandon \& Shome, 2009; Glosny, 2010; Bell, 2011; Cameron, 2011). That is, the BRICS appears to have neither political nor economic merit as a set in international relations.

\subsection{BRICS Set Principles}

The June 2009 founding summit of the original BRICs in Russia focused on financial matters only to expose the deep geopolitical discrepancies of the set (Tandon \& Shome, 2009). The set's existing economic, business, financial, political and social discrepancies will inevitably precipitate conflict in the member states' trade relations, especially because of their reverence of state capitalism and heavy reliance on SOEs in the engagement of international relations. Whereas the BRICS set has continued to struggle for a coherent vision, the grouping has adopted ten principles that signify it as a nonbloc arrangement. Notwithstanding the establishment of the BRICS Bank, individual member states continue to reserve the right to conduct international relations in their national self-interests. The latter are for all countries of the world contradictory and deeply non-complementary. As already noted, the ongoing international relations conflict involving the EU, USA and Russia over the war in Ukraine reveal the political impotence of the BRICS set. From the economic perspective, five of the ten BRICS set principles demonstrate that member states will remain disparate entities because they are all engraved in the globalist neoliberal modernity ethos. The five pertinent principles are: centrality of multilateralism on global issues; mutual respect for one another's choice of the development path; openness; non-bloc nature; and, neutrality with regard to third parties (BRICS, 2013). As already stated, the establishment of the BRICS set has not agitated for any notable transformation of the traditional global economic and trade relations (Haq \& Meilke, 2009). Indeed, the BRICS set has become more striking as a "declaratory", than "operational", force; and, the grouping's vivid impact has been in setting up an international scenario wherein competition, rather than cooperation, would become intense and fierce (Cooper, 2009). The BRICS member states' individual uniqueness, rather than collective identity, stands out starkly; unsurprisingly, Cooper (2009, n.p.) observes that:

"In many ways, nevertheless, the BRICs are more interesting for their differences than their similarities. Brazil and India are robust democracies. Russia is a managed democracy. China is a one party state. India has a fast rising population. Russia is in serious demographic trouble with a sharply reduced life expectancy. Brazil and Russia are resource rich. India and China are resource dependent".

There can be no significant and effective catalyst for political and economic conflict among global actors in international relations than these disparities of the BRICS set under state capitalism, and SOEs acting on the global stage as though they were private multinational corporations as well as intense openness and multilateralism in global trade and FDI. The BRICS set's adherence to "non-discrimination" and treatment of all countries virtually equally (Olanrewaju, 2007, p.6), amidst the World Trade Organization (WTO) provisions that existing regional arrangements amounting to a departure from the Most Favoured Nation (MFN) principle would only be acceptable if "the tariff applying to external parties is not, on the whole, higher than the tariffs previously in force" (Davies, 1996, p.34), would enforce dangerously lower tariffs for member sates such as South Africa and Brazil that have already applied economic reforms and trade liberalization strategies.

Inevitably, adherence of the BRICS set to these principles will breed diverse and divergent futures among member 
states, thereby reinforcing the propensity for economic and political conflict through incoherent conduct of international relations. As a non-bloc set, the BRICS grouping will incrementally be weakened as and when member states continue to display "differential rates of growth in most macro-indicators" (Tandon \& Shome, 2009, p.273). Reverence for economic freedom policies for openness to multilateral trade and FDI (Bell, 2011) will inescapably serve as catalyst for economic conflict within the BRICS set. Also, the five member states of the BRICS set are geographically, ideologically, culturally and historically in starkly diverse and, in some cases, contradictory contexts (Cooper, 2009), which would precipitate political and economic conflict in their conduct of international relations. Besides global openness being "methodologically and theoretically" inappropriate for the BRICS economies (Oyejide, 2000), wholesale adoption of economic freedom policies will render intra-set "cross-border trade merely derivative from general trade liberalization" (Weeks, 1996, p.5), thereby setting member states up for intra-group economic conflict.

\subsection{State Capitalism Governance in the BRICS Set}

The adoption of state capitalism governance among the BRICS member states is based on the assumption that public institutions are necessary for the supplementation of the invisible market-hand, in order to ensure ingenuity in supporting national public interest mandates (Glemarec \& Puppim de Oliveira, 2012; Yi-Chong, 2012). Indeed, states are capable of providing institutions capable of optimal governance for service of national public interest mandates (Glemarec \& Puppim de Oliveira, 2012). But state capitalism governance reinforces collusion of the state with free markets in creating "bureaugarchs" and "apparatchiks" out of capitalists and politicians, without any public accountability other than commitment to servicing the interests of shareholders (Gabriel, 2003; Musacchio \& Flores-Macias, 2009; Xu, 2010; Scissors, 2011; Bacon, 2012; Yi-Chong, 2012; Musacchio, 2013). As Yi-Chong (2012) states, state capitalism in emerging economies is intricately interconnected with a nuance hybrid of "giant and opaque" SOEs that operate on the global stage as if they were private multinational corporations. Through state capitalism and this nuance hybrid of SOEs, emerging economies have simultaneously "learned to leverage the power of government .... (and) the rules of the market" (Musacchio cited in Harvard Business School, 2013, p.3). Under state capitalism, public institutions are designed to legitimize corporate governance and restructuring wherein the core of the political-economy of SOEs resides firmly "in their domestic politics" (Yi-Chong, 2013, p.3). The BRICS economies are driven by momentous public expenditure in industrial production for SOEs "national champions". By extension, the political-economy of state capitalism in the BRICS set will be experienced in the governance and structuring of domestic strictures of poverty and inequality. Philosophically and ideologically, insight on SOEs could potentially enhance understanding of the political-economy effects of state capitalism varieties, domestically (Hall \& Soskice, 2001; Gabriel, 2003; Musacchio \& Flores-Macias, 2009; Xu, 2010; Scissors, 2011; Bacon, 2012; Yi-Chong, 2012; Musacchio, 2013).

\section{State-Owned Enterprises, Societal Poverty and Inequality in the BRICS Set}

The BRICS set's governance of economics and politics is commonly described in the concept of state capitalism, which manifests through a selection and public funding of a few "national champion" SOEs that are allowed to operate on the global stage as if they were private multinational corporations. Inevitably, state capitalism everywhere else in emerging economies is associated with societal poverty and inequality because it discourages social investment of public funds.

\subsection{BRICS Set and State-owned Enterprises}

In the BRICS set, practice of capitalism is described variously as "Red Capitalism" for China, "capindialism" for India, sate socialism for Russia, private capitalism for Brazil and liberal capitalism for South Africa. Fundamentally, these are varieties of state capitalism that reflexively restructure public institutions, specifically the SOEs, for state supplementation of the free markets (Kolo, 2008; Bradley \& Donway, 2010; Dean, Browne \& Oster, 2010; Karon, 2011; Coy, 2012; Goryunov, 2012; Lubman, 2012; Webb, 2012; Yi-Chong, 2012). In practice, SOEs are a common feature of the world economy, captured in nomenclature such as government-owned corporations (GOCs), public sector undertakings (PSUs) or public sector enterprises (PSEs) (Investopedia, n.d.; Wikipedia, n.d.). These state-owned entities consist of "a legal entity created by a government to undertake commercial activities" on behalf of government (Investopedia, n.d.; Wikipedia, n.d.); to this extent, their restructuring and operations are at the centre of state capitalism governance. Typically, SOEs are earmarked to participate in global commercial activities to serve government's business, financial interests, notwithstanding justification of their establishment on the basis of public policy objectives that are "purely nonfinancial" (Bradley \& Donway, 2010). 
The nuance hybrid of SOEs is established as "a variety of public-private" partnership corporate governance-style legal entity (Gabriel, 2003; Musacchio \& Flores-Macias, 2009; Xu, 2010; Scissors, 2011; Bacon, 2012; Yi-Chong, 2012; Musacchio, 2013). These SOEs have a distinct legal form that provides for freedoms of operation in commercial affairs with financial goals, shareholding and directorships (Yi-Chong, 2012). Given the momentous public funds support entailed, state capitalism governance has been associated with careful selection of a few SOEs that would be promoted as national "champions". The latter giant and opaque corporations, that gobble public funds as national monopolies, oligopolies and/or duopolies, experiment with global stock exchange listing and market expansionism (Gabriel, 2003; Musacchio \& Flores-Macias, 2009; Xu, 2010; Scissors, 2011; Bacon, 2012; Yi-Chong, 2012; Musacchio, 2013). This restructuring implies that accountability of SOEs is, exclusively, to government shareholders (Bradley \& Donway, 2010; Yi-Chong, 2012). Under state capitalism, governance and restructuring of the nuance hybrid of SOEs determine the nature and extent of domestic political-economy of poverty and inequality because these entities are "common with natural monopolies and infrastructure such as railways and telecommunications, strategic goods and services (mail, weapons), natural resources and energy, politically sensitive business, broadcasting, demerit goods (alcohol) and merit goods (healthcare)" (Wikipedia, n.d.). Unsurprisingly, BRICS member states' conduct of global economics is predicated on their "national champions" activities (Yi-Chong, 2012). Therefore, the BRICS set's domestic strictures of poverty and inequality is inextricably connected to the conduct of their SOEs on the global stage. According to Bacon (2012, p.1), "the spread of a new sort of business in the emerging world will cause increasing problems", largely because of the nature of their corporate governance and structuring.

\subsection{Societal Poverty and Inequality in the BRICS Set}

The urge and potential for economic conflict is palatable in the BRICS set. Except for India, the GDP growth rates for all other member states have been on the downward trend between 2011 and 2012 (Figure 1). To this extent, it can be expected that each of these countries would seek to use its power capabilities within the set to export poverty and import wealth. This would be made possible because of the set's conditionalities and principles of openness. The GDP growth rates for India are extraordinarily high but unreliable because in the BRICS (2013) joint statistical publication, this country's values were missing.

Figure 1: BRICS set GDP growth and unemployment rates, 2011-2012

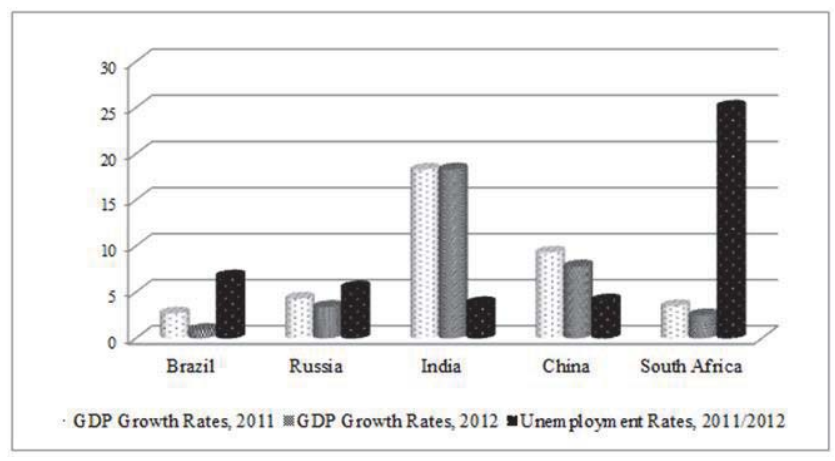

Source: BRICS (2013)

But available evidence shows that GDP growth rates trended downwards for all BRICS member states between 2011 and 2012, which raises questions of the appropriateness of the economic freedoms policies and state capitalism. Only South Africa recorded double digit unemployment rate of the BRICS set. Discrepancies in these macro-economic indicators in the BRICS set render collaboration in international relations virtually unworkable because of the conflictual nature of the appropriate policies and interventions required. These discrepancies will exacerbate the stark diversity of the BRICS member states' cultures, histories and ideologies, thereby catalysing the national propensity for pursuing civilizing missions within the set.

On average, it appears that Russians, Brazilians, South Africans, Chinese and then Indians, in this particular order, have relatively better living standards as measured through the per capita GDP 2011/2012 prices (Figure 2). Evidently, there are three categories in this regard. India is alone in the low per capita GDP bracket, whilst South Africa and China 
are in the middle and Russia and Brazil in the relatively higher living standards. It is imperative to point out that these per capita GDP values do not match the GDP growth rate patterns in the BRICS set (see Figure 1). The diverse, apparently conflictual, societal living standards would unavoidable precipitate economic competition in the set; and, economic conflict among the diverse actors would become unavoidable, especially because SOEs that are fully funded through public fiscus operate as if they were private multinationals. Chinese SOEs are already predominant in their investment across the world; and, they would be expected to do the same in the BRICS set.

Figure 2: BRICS set per capita GDP, 2011-2012

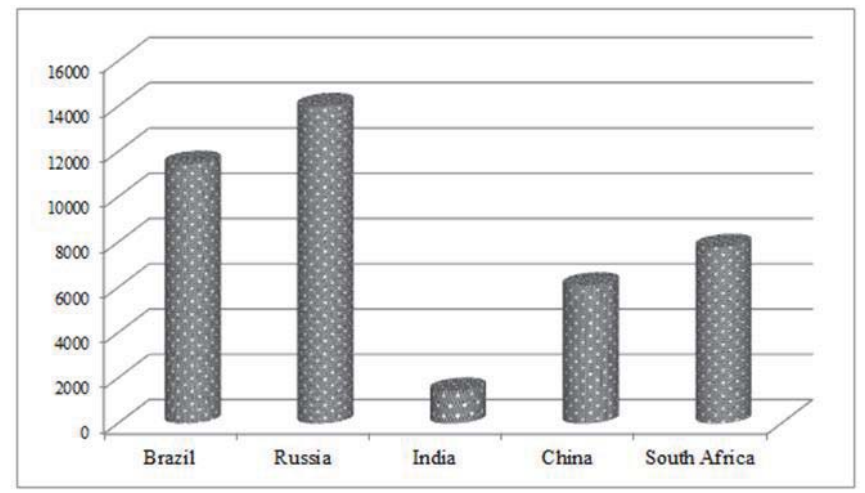

Source: BRICS (2013)

Public pressure too would be brought to bear, with the potential of fuelling the intensity of economic conflict through the visible hand behind the SOEs. The propensity to engage in fierce economic conflict is evident in the share of public investment expended in education, health and industrial production as a percentage of GDP. Except for Brazil where the 2012 public investment expended in industrial production declined from that of 2011, the rest of the set has experienced comparable increases; conversely, public investment expended in the social fabric of societies as percentage of GDP has declined between 2008 and 2012, except for marginal increases in China and Brazil (Figure 3). The uniformity of emphasis on public funds invested in industrial production to the virtual neglect of social expenditure on education and health highlights the problem of economic freedom policies being adopted as one-size-fits all in the BRICS set, when the member states' differentness is so stark. The excessive emphasis on expenditure of public funds on industrial production, relative to that on education and health, demonstrates the state reverence for globalist neoliberal modernity above distributive justice. In this context, domestic poverty and inequality become instructive in respect of the potential for social instability. Yet, as already indicated, the GDP growth rates have remained low and declining, except for the unreliable Indian statistics (see Figure 1).

Figure 3: BRICS set share of public investments expended as percentage of GDP, 2008-2012

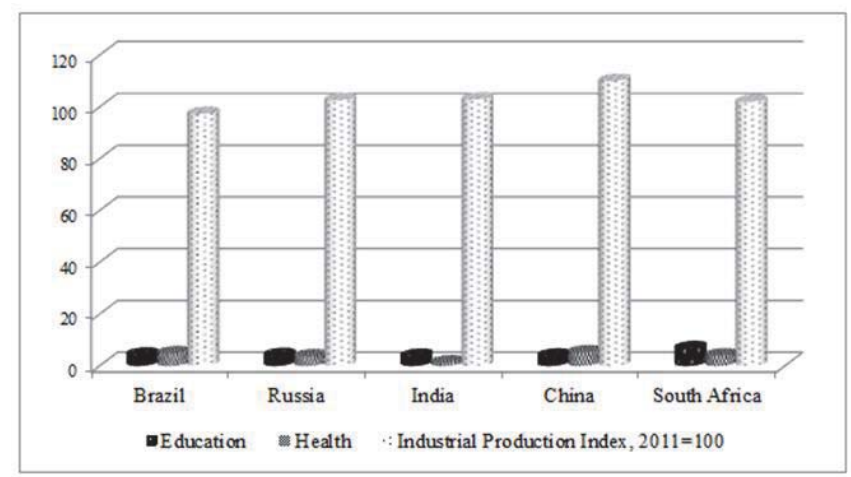

Source: BRICS (2013) 
The United Nations Development Programme (UNDP, 2014) Human Development Report shows that in 2013 the headcounts for multidimensional poverty index (MPI) for BRICS countries, with the exception of Russia where statistics are missing, were significant because of the percentage intensity of deprivation. The MPI refers to the percentage of population with a weighted deprivation score of at least 33\% (UNDP, 2014). India is the poorest and Brazil is the least poor, relative to the four BRICS member states where statistics are available (Figure 4).

Figure 4: Multidimensional poverty index, intensity of deprivation and poverty rate of the BRICS set, 2012

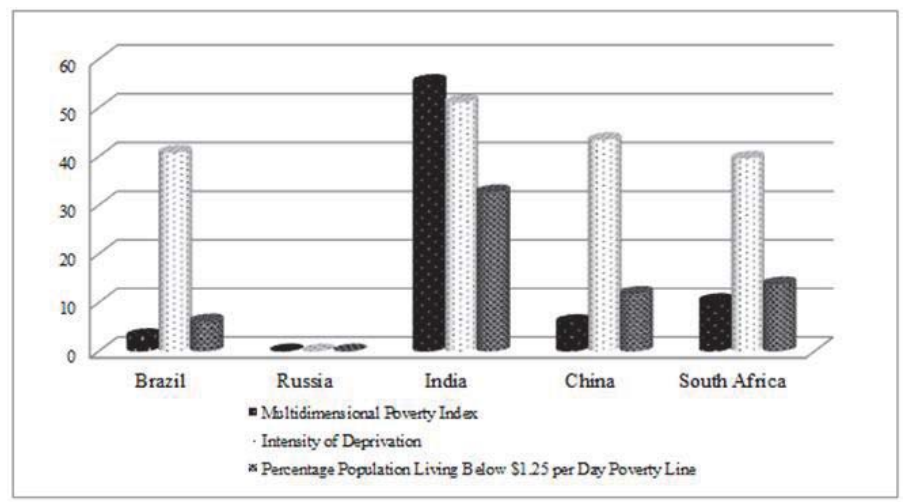

Sources: BRICS (2013); UNDP (2014)

For these four BRICS member states, the intensity of deprivation is deep; and, globalist neoliberal modernity policies will exacerbate this situation, yet social investment of public funds as percentage of GDP has remained low compared to the growth-less public expenditure in industrial production (see Figure 3). In all likelihoods, the latter public investments involve funding of the giant and opaque SOEs "national champion" monopolies, oligopolies and duopolies. That is, the BRICS member states' hope that SOEs would precipitate economic growth which would become a panacea for resolving domestic poverty and inequality has evaporated into thin air. Measured through the gini-coefficient, the 2011/2012 inequality has unsurprisingly remained significantly high among the BRICS countries, except for India where it has been very low (Figure 5).

Figure 5: BRICS set gini-coefficient inequalities, 2011/2012, and HDI, 2013

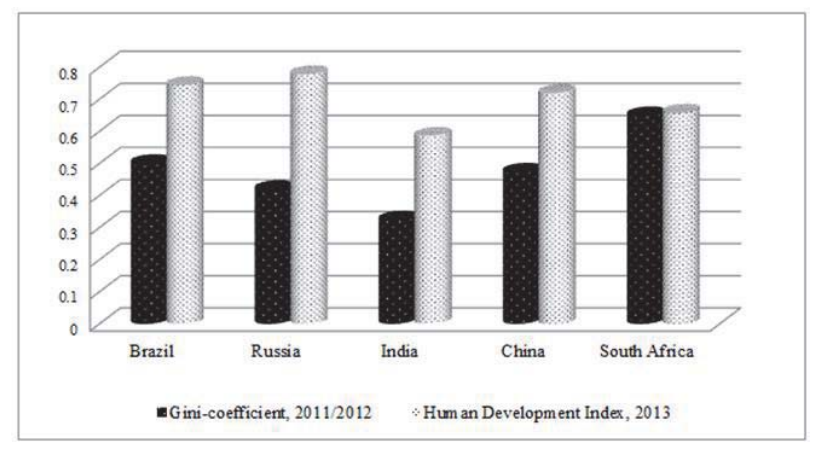

Source: UNDP (2014)

From the inequality perspective, there are three categories in the BRICS set. One consists of relatively low levels of inequality of India, the other includes medium inequalities of Russia and China as well as that for high inequalities of Brazil and South Africa. Using the 2013 data, the UNDP (2014) classifies Russia, Brazil and China as high HDI countries numbers 57, 79 and 91, respectively, of the 187 countries of the world which consists of the very high, high, medium and low HDI. But the domestic inequalities in these three countries are higher than that for India (see Figure 5) which is 
classified in the same UNDP (2014) Human Development Report as a medium HDI country. Similarly, South Africa's HDI surpasses that for India, whilst its inequality is deeper than that for India, despite both being classified into the same category of medium HDI countries in the UNDP (2014) Report. According to the UNDP (2014) Report, India is the lowest ranked BRICS member state in the 187 countries of the world at 135, followed by South Africa at 118. It is evident that the BRICS set consists of countries that cannot even be loosely classified together as emerging economies; instead, the grouping consists of disparate polities as evinced in the measures of HDI, inequality, MPI, intensity of deprivation, poverty rate, per capita GDP and GDP growth rates. Each of the BRICS member states would most certainly be pressured by the BRICS set to pursue globalist neoliberal modernity policies and deployment of "national champion" SOEs for commercial and financial interests within international relations at the expense of making the necessary social investments. The unproductive public funding of SOES in the BRICS set is concomitant with the perpetuation of the domestic politicaleconomy of poverty and inequality.

\section{Conclusion}

This article demonstrated that the contemporary international relations are complex and in a state of continuous flux, perpetually shaped and reshaped by a variety of state and non-state global actors. It argued that some global actors pursue civilising missions that serve their nationalist self-interests and objectives, hoping to undermine in the process the stark cultural, historical and ideological diversities in the world-economy. To this extent, the article highlighted the propensity that the BRICS set would seek to do the impossible; that is, it would attempt to undermine member states' uniqueness in cultures, histories and ideologies by artificially imposing globalist neoliberal modernity using public institutions to supplement the invisible hand of the free markets, under state capitalism governance. The latter is evident in all BRICS member states as evidenced by the heavy reliance on the nuance hybrid of "national champion" SOEs that operate on the global stage as if they were private multinational corporations, despite being established on the basis of public policy objectives. The article concludes that reverence for state capitalism and SOEs in the BRICS set is a flagrant disregard of the member states' differentness of macro-economic indicators such as HDI, inequality, MPI, intensity of deprivation, poverty rate, per capita GDP and GDP growth rates.

\section{References}

Alloggio, S. \& Thomas, K. 2013). Resisting the lure of deferral: Realizing the South African National Development Plan. Social Dynamics: A Journal of African Studies, 39(1), 108-110.

Bacon, D. (2012). Emerging-market multinationals: the rise of state capitalism. The Economist, [Online] Available: http://www.economist. com/node/21543160/print (March 17, 2013).

Bell, H.A. (2011). Status of the "BRICS": an analysis of growth factors. International Research Journal of Finance \& Economics, 69, 1925.

Biko, H. (2013). The Great African Society: A Plan for a Nation Gone Astray. Johannesburg: Jonathan Ball.

Bradley, R. \& Donway, R. (2010). Capitalism, socialism, and "the middle way": A taxonomy. Independent Review, [Online] Available: http://www.highbeam.com/doc/igi-230865752.html (March 17, 2013).

BRICS, (2013). BRICS: Joint Statistical Publication 2013. Durban: BRICS.

Cameron, F. (2011). The EU and the BRICs. The Jean Monnet Multilateral Research Network on the Diplomatic System of the European Union, Policy Paper 3, February 2011, Loughborough University, London.

Chandler, D. (2006). Empire in Denial: the Politics of State-building. London: Pluto Press.

Chua, A. (2007). Days of Empire: How Hyperpowers Rise to Global Dominance and Why they Fall. New York: Doubleday.

Cooper, A. F. (2009). Picking your Club: G8 or G20, BRICs or B(R)ICSAM? Keynote Presentation to Oxfam International on the BRICSAM and the Fight against Global Poverty, July 13, 2009, Geneva.

Coy, P. (2012). China's state capitalism trap. Bloomberg Businessweek, [Online] Available: http://www.businessweek.com/printer/ articles/7930-chinas-state-capitalism-trap (March 17, 2013).

Davies, R. (1996). Promoting regional integration in Southern Africa: an analysis of prospects and problems from a South African perspective. African Security Review, 5, 27-38.

Dean, J., Browne, A. \& Oster, S. 2010. China's 'state capitalism' sparks a global backlash. The Wall Street Journal, [Online] Available: http://online.wsj.com/article/SB10001424052748703514904575602731006315198.html (March 17, 2013).

Desai, A., Maharaj, B. \& Bond, P. (2011). Introduction: Poverty eradication as Holy Grail. In B. Maharaj, A. Desai \& P. Bond (Eds.), Zuma's Own Goal: Losing South Africa's "War on Poverty" (pp.1-35). Trenton: Africa World Press, Inc.

Gabriel, S.J. (2003). Chinese Capitalism and the Modernist Vision. London: Routledge.

Glemarec, Y. \& Puppim de Oliviera, J.A. (2012). The role of the visible hand of public institutions in creating a sustainable future. Public Administration and Development, 32, 200-214.

Glosny, M.A. (2010). China and the BRICs: a real (but limited) partnership in a unipolar world. Polity, 42(1), 100-129. 
Goodall, B. (1987). Dictionary of Human Geography. London: Penguin Books.

Goryunov, F. (2012). What kind of capitalism has Russia built? Rossiyskaya Gazeta, [Online] Available:http://rbth.ru/articles/ 2012/03/23/what_kind_of_capialism_has_russia_built_15160.html (March 17, 2013).

Harvard Business School, (2013). What capitalists should know about state-owned enterprises? Forbes, Harvard Business School Working Knowledge. [Online] Available: http://www.forbes.com/sites/hbsworkingknowledge/2013/02/22/ (March 17, 2013).

Habib, A. (2013). South Africa's Suspended Revolution: Hopes and Prospects. Johannesburg: Wits University Press.

Hall, P.A. \& Soskice, D. (2001). Varieties of Capitalism: the Institutional Foundations of Comparative Advantage. Oxford: Oxford University Press.

Haq, Z. \& Meilke, K. (2009). The role of income growth in emerging markets and the BRICs in agrifood trade. Canadian Agricultural Trade Policy Research Network (CATPRN) Working Paper 2009-02, February 2009, Ontario: CATPRN.

Hardt, M. \& Negri, A. (2000). Empire. Cambridge, MA: Harvard University Press.

Hsing, Y. (2011). The stock market and macroeconomic variables in a BRICS country and policy implications. International Journal of Economics and Financial Issues, 1(1), 12-18.

Huggett, R. \& Robinson, M. (1996). Introduction. In I. Douglas, R. Huggett \& M. Robinson M. (Eds.), Companion Encyclopedia of Geography: The Environment and Humankind (pp.159-161). London: Routledge.

Investopedia, (n.d.). State-owned Enterprise (SOE) Definition. [Online] Available: http://www.investopedia.com/terms/s/soe.asp (March 17, 2013).

Karon, T. (2011). Why China does capitalism better than the U.S. Time, [Online] Available: http://www.time.com/time/world/article/ $0,8599,2043235,00 \cdot \mathrm{html}$ (March 17, 2013).

Kearns, G. (2009). Geopolitics and Empire: the Legacy of Halford Mackinder. Oxford: Oxford University Press.

Kolo, V. (2008). China's capitalist counter-revolution. Socialism Today, [Online] Available: http://www.socialismtoday.org/114/china.html (March 17, 2013).

Koppel, B. (Ed.) (1990). Structural Adjustment and Policy Reform: Impacts on Small and Medium Enterprises in the Asian Economies. Tokyo: Asian Productivity Organization.

Langton, J. (1996). The origins of the capitalist world economy. In I. Douglas, R. Huggett \& M. Robinson (Eds.), Companion Encyclopedia of Geography: The Environment and Humankind (pp.206-227). London: Routledge.

Legum, M. (2002). It Doesn't Have to be Like This! A New economy for South Africa and the World. Kenilworth: Ampersand.

Lubman, S. (2012). China's state capitalism: the real world implications. The Wall Street Journal (WSJ), [Online] Available: http://blogs.wsj.com/chinarealtime/2012/03/01/china-state-capitalism-the-real-world-implications/ (March 17, 2013).

MacDonald, P.K. (2009). Those who forgot historiography are doomed to republish it: Empire, imperialism and contemporary debates about American power. Review of International Studies, 35, 47-54.

MacFarlane, S.N. (2006). The "R" in BRICs: is Russia an emerging power? International Affairs, 82(1), 41-57.

Marais, H. (2001). South Africa: Limits to Change, the Political Economy of Transition. (2nd ed.). Cape Town: University of Cape Town Press.

Mbeki, M. (2009). Architects of Poverty: Why African Capitalism Needs Changing. Johannesburg: Picador Africa.

Mkandawire, T. (2011). Running while others walk: Knowledge and the challenge of Africa's development. Africa Development, 36(2), 136.

Musacchio, A. (2013). What capitalists should know about state-owned enterprises. Harvard Business School Working Knowledge, [Online] Available: http://www.forbes.com/sites/hbsworkingknowledge/2013/02/22/what-capitalists-should-know-about-stateowned-enterprises (March 17, 2013).

Musacchio, A. \& Flores-Macias, F. 2009. The return of state-owned enterprises. Harvard International Review, [Online] Available: http://hir.harvard.edu/the-return-of-state-owned-enterprises? (March 17, 2013).

Nabudere, D.W. (2006). Development theories, knowledge production and emancipation practice. In V. Padayachee (Ed.), The Development Decade? Economic and Social Change in South Africa, 19994-2004 (pp.33-52). Pretoria: HSRC.

O'Neill, J., Wilson, D., Purushothaman, R. \& Stupnytska, A. (2005). How solid are the BRICs? Goldman Sachs Global Economics Paper No. 134, [Online] Available: https://portal.gs.com (June 12, 2013).

Orrell, D. (2010). Economyths: Ten Ways that Economics Gets it Wrong. London: Icon Books.

Oden, B. (1999). New regionalism in Southern Africa: part of or alternative to the globalisation of the world economy? In B. Hettne, A. Inotai \& O. Sunkel (Eds.), Globalism and the New Regionalism, Vol. 1. London: Macmillan.

Olanrewaju, S.A. (2007). Aid for Trade: Prospects for Enhancing African Trade Capacity. [Online] Available: http://www.afdb.org/pls/ portal/url/item/3da174d19adb3c0fe040c00a0c3d5277 (November 10, 2008).

Parker, N. (2010). Empire as a geopolitical figure. Geopolitics, 15(1), 113-114.

Persons, R. (2013). ZUMANOMICS Revisited: The Road from Mangaung to 2030. Sunnyside: Jacana.

Pitts, J. (2005). A Turn to Empire: the Rise of Imperial Liberalism in Britain and France. Princeton: Princeton University Press.

Pomeranz, K. (2005). "Civilizing" Missions, past and present. Daedalus, 134, 34-45.

Qwabe, B.R. (2013). Realizing South Africa's Vision 2030: A capacity-building perspective. Administratio publica, 21(2), 21-36.

Scissors, D. (2011). Chinese state-owned enterprises and U.S: China economic relations. Testimony before the U.S.-China Economic \& Security Review Commission, March 30, 2011, [Online] Available: http://www.heritage.org/research/testimony/2011/04/chinesestate-owned-enterprises-and-us-china-economic-relations (March 17, 2013).

Simon, D., van Spengen, W., Dixon, C. \& Narman, A. (Eds.) (1995). Structurally Adjusted Africa: Poverty, Debt and Basic Needs. 
London: Pluto Press.

Tandon, S. \& Shome, S. (2009). The cracks in the BRICS. Annals of the University of Petroşani, Economics, 9(4), $273-282$.

United Nations Development Programme (UNDP), (2014). Human Development Report 2014 - Sustaining Human Progress: Reducing Vulnerabilities and Building Resilience. New York: UNDP.

Webb, N. (2012). State capitalism: a choice of models, theme and variations. The Economist, http://www.economist.com/ node/21542924/print (March 17, 2013).

Weeks, J. (1996). Regional cooperation and Southern African development. Journal of Southern African Studies, 22, 99-117.

Wikipedia, n.d. Government-owned Corporations. [Online] Available: http://www.en.wikipedia.org/wiki/Government-owned_Corporation (March 17, 2013).

Wilson, D., Kelston, A.L. \& Ahmed, S. (2010). Is this the "BRICs decade"? BRICs Monthly, 10(3), 1-4.

Wilson, D. \& Purushothaman, R. (2003). Dreaming with BRICs: the path to 2050. Global Economics Paper No. 99, October 01, 2003, Goldman Sachs.

Xu, G. (2010). State-owned enterprises in China: how big are they? East Asia \& Pacific on the Rise, [Online] Available: http://blogs.worldbank.org/eastasiapacific (March 17, 2013).

Yi-Chong, X. (Ed.) (2012). The Political Economy of State-owned Enterprises in China and India. London: Palgrave Macmillan.

Zielonka, J. 2012). Empires and the modern international system. Geopolitics, 17(3), 502-525. 